\title{
The influence of breakfast on the academic performance of school-age adolescents: systematic review*
}

\author{
Eun-Young Jeong ${ }^{\dagger}$ \\ Department of Nursing, Woosong University, Daejeon 34606, Korea
}

\begin{abstract}
Purpose: This review article provides an overview of the importance of breakfast by examining the relationship between breakfast and academic achievement including the papers published in Korean. Methods: This study searched a total of six domestic and international databases. The main search words for searching the database were 'breakfast,' 'morning meal,' 'adolescent,' 'teen or teenage,' 'children' and 'academic performance,' and used search operators when available such as 'breakfast AND adolescent AND academic performance'. Results: We searched a total of 274 studies through six databases and included a total of 15 primary studies in which 12 studies were cross-sectional and three were cohort studies. Since a quantitative integration of the primary studies was difficult to achieve such as performing a meta-analysis, this study performed a descriptive analysis of all the 15 studies and the results have shown that eating breakfast has a significant effect on academic achievement. In other words, students who regularly had breakfast showed more than twice the academic performance compared to those who did not have breakfast, and even though the math scores of students who had breakfast were statistically significantly higher, none of the study results inferred the reason. Conclusion: This study showed the importance of eating breakfast during adolescence by presenting that academic achievement increases with regular or more frequent habits of eating breakfast.
\end{abstract}

KEY WORDS: breakfast, adolescent, academic performance, systematic review

\section{Introduction}

As living standards have improved and the interest in health has increased, the interest in breakfast has been on the rise as well. In particular, the importance of breakfast is being emphasized with the release of research reports stating that breakfast affects health as well as the academic performance of school-age children and adolescents. However, school-age children and adolescents in Korea choose sleeping over breakfast due to lack of sleep and late sleeping hours because of evening self-study and private institute classes, so the late night life patterns affect both the evening and the morning. According to the 2014 National Health and Nutrition Survey, the rate of skipping breakfast was the highest for both male and female in their 20s (male: $45.1 \%$, female: $36.4 \%$ ), followed by adolescents between the age of 12 and 18 (male: $33.2 \%$, female: $28.6 \%$ ), and the rate was higher in city areas than in rural areas with lower income levels [1].

Studies of how breakfast affects the cognitive ability or academic performance are somewhat different from earlier studies and recent studies. In other words, in terms of early studies around the 1990s, there was no statistically significant difference between students who had breakfast and those who skipped breakfast in terms of short-term memory, finding the duplicated spelling of any given alphabet, and simple addition problems [2]. There was no difference in short-term visual memory, level of arousal, degree of impulsiveness, and mood state [3] and no influence on problem solving abilities and concentration [4]. However, Wyon et al. [5] showed statistically significant negative results in creative thinking in terms of comparing a group of 10-year-old school age children that had low calorie and nutritionally insufficient breakfast with a group that had a healthy breakfast. They reported that the children who had breakfast with relatively low

Received: February 11, 2019 / Revised: February 21, 2019 / Accepted: February 27, 2019

* This work was supported by the Woosong University research fund (2019-0403).

$\dagger$ To whom correspondence should be addressed.

tel: +82-042-630-9355, e-mail: silver@wsu.ac.kr

This is an Open Access article distributed under the terms of the Creative Commons Attribution Non-Commercial License (http://creativecommons. org/licenses/by-nc/3.0/) which permits unrestricted non-commercial use, distribution, and reproduction in any medium, provided the original work is properly cited. 
calories complained more about hunger and depression. In addition, skipping breakfast reduced attention or short-term memory, and this phenomenon has been reported to get worse over the morning hours [6]. The interest in habit of eating breakfast and academic achievement is also very high in Korea. According to the study on middle and high school students, students who eat breakfast every day showed up to 1.7 times higher academic results than students who did not eat breakfast at all [7]. The same results were shown even after controlling various variables, and the breakfast eating habits of female students were more closely related to academic achievement than that of male students [7].

As the importance of breakfast continues to be reported, a growing number of countries are providing breakfast at school for school-age children who skip breakfast due to busy morning schedules. In Korea, the Seoul Metropolitan Government has operated the 'Good morning breakfast club,' a program that provides breakfast for middle and high school students since 2008, which led to an increased frequency of eating breakfast, improved eating habits and dietary intake status, and also improve school life, showing an effect more than just a breakfast [8].

To date, primary studies on how breakfast is related to academic achievement have been performed in Korea [7,9-11] In addition, systematic literature reviews have been performed frequently in other countries, but the literature included were mainly limited to primary studies published in English with mixed results on academic achievement and cognitive abilities $[12,13]$. Therefore, the purpose of this study is to consider the importance of breakfast by examining the relationship between breakfast and academic achievement including the papers published in Korean.

\section{Methods}

\section{Search database and key words}

The core question of this study is whether breakfast is related to the academic achievement of school-age children and adolescents, and for the purpose, this study searched a total of six domestic and international databases, including domestic databases of KmBase, KoreaMed, and riss $4 u$, and international databases of PubMed, Cochrane library, and MEDLINE. There was no limit on the search period for searching the database, and every literature corresponding to the relevant key words up to the current search date (July 30, 2018) were searched. In addition, if a document was found which was not searched through the database by examining the references of the literature selected by the selection criteria, the corresponding literature was searched and included in the analysis if it satisfied the selection criteria.

The main search words for searching the database were 'breakfast,' 'morning meal,' 'adolescent,' 'teen or teenage,' 'children' and 'academic performance,' and used search operators when available such as 'breakfast AND adolescent AND academic performance'.

\section{Criteria for selecting and excluding literature}

The primary studies included in this study are studies published in English and Korean, where we selected studies with peer reviews. The detailed criteria for selection and exclusion are as follows.

\section{Participants}

Studies on school-age adolescents, from elementary school to college students were included and studies on adults, senior citizens, or patients were excluded.

\section{Interventions}

This study included breakfast in any form (e.g. breakfast at home or in school breakfast programs (SBP)), and excluded studies on lunch, dinner or snacks. The definition of breakfast was not defined separately or limited in this study and included the parts defined as breakfast in the primary studies.

\section{Outcomes}

Academic achievement included studies that analyzed the overall Grade Point Average (GPA), or individual subject scores in English or mathematics. However, studies on cognitive performance were excluded in our review.

\section{Study designs}

This study included all types of research such as experimental studies of short and long-term analysis, non-experimental studies such as cross-sectional studies, cohort studies, and before-and-after studies.

\section{Process for selecting literature}

Based on the literature search strategy, this study 


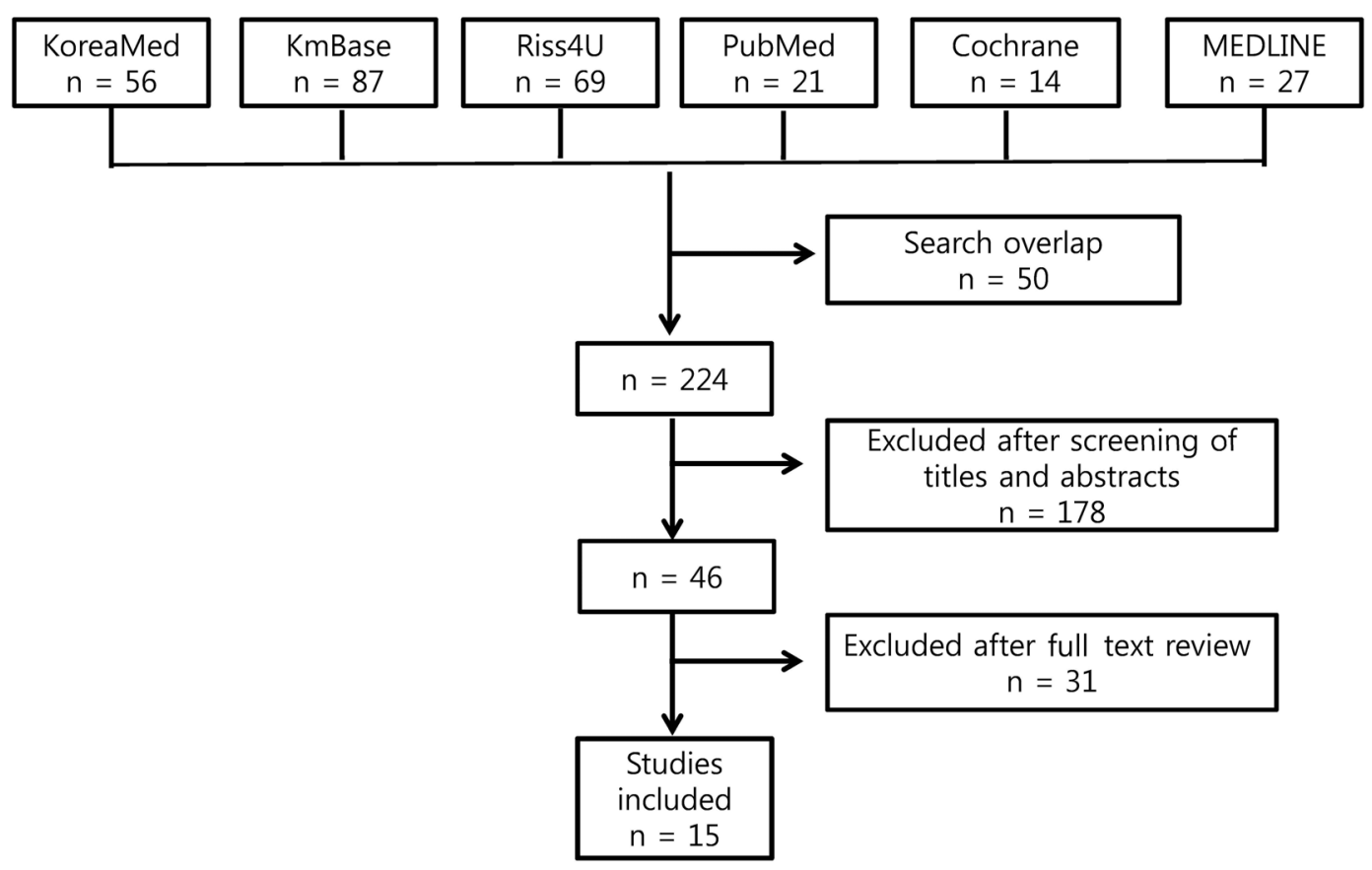

Fig. 1. Flow diagram of the study selection process

collected all literatures from each database and removed duplicate documents. After removing duplicate documents, studies that did not match the core question of this study were excluded through screening the title and abstract of the primary studies. This was followed by a full text review for primary studies that fully complied with the selection criteria or were unclear whether to select or exclude based on the title and abstract, to make the final decision (Fig. 1).

\section{Data extraction}

The data were extracted by two researchers and summarized by: 1) author and year, 2) research type, 3) characteristics of the subjects, 4) definition and type of breakfast, 5) measurement method and type of academic achievement, and 6) results.

\section{The results of assessing the quality of the primary studies}

The 15 studies that were included consisted of 12 cross-sectional studies and three cohort studies. We used the Newcastle-Ottawa Quality Assessment Scale (NOS) for cohort studies and NOS for cross-sectional studies to assess the risk of bias [14]. The NOS divides the area of bias into three domains such as selection of study groups, comparability of groups and ascertainment of exposure/ outcome. The NOS evaluates the bias of the literature with eight questions for cohort studies and six questions for cross-sectional studies. In addition, each question is marked with a star for the answer that considers the research method to be a low risk of bias, and no stars for high risk of bias or if there is no study report on the item. Although NOS cohort studies can be given up to nine stars and cross-sectional studies up to seven stars, there are no standards for how many stars indicate the high quality of the literature due to low risk of bias.

In terms of the studies with low risk among the 12 studies, nine out of twelve cross-sectional studies randomly selected the subjects as the representative of the study subjects or, to some extent, selected a group that can represent the study without random sampling. On the other hand, studies that perform a blinded experiment on the outcome variables or extract the outcome variables from medical records when measuring the results are considered to be qualitatively good, but most of the cross-sectional studies included in this study were judged to have a high risk of bias due to the usage of self-administered questionnaires. In addition, nine out of twelve cross-sectional studies did not provide a separate analysis on the dropouts who did not answer the questionnaires, therefore, no comparison was made between the characteristics of the subjects and 
122 / The influence of breakfast on the academic performance: systematic review

Table 1. Summary of quality assessment for cross sectional studies

\begin{tabular}{|c|c|c|c|c|}
\hline Quality & assessment criteria for cross sectional study & $\begin{array}{l}\text { High quality } \\
\left(\text { Low RoB }{ }^{11}\right)\end{array}$ & $\begin{array}{l}\text { Low quality } \\
\text { (High RoB) }\end{array}$ & Unclear \\
\hline \multirow{3}{*}{$\begin{array}{l}\text { Selection } \\
\text { (Maximum } 3 \text { stars) }\end{array}$} & Representativeness of the sample & 9 & 3 & - \\
\hline & Non-respondents & 1 & 2 & 9 \\
\hline & Ascertainment of the exposure (risk factor) & 7 & 5 & - \\
\hline $\begin{array}{l}\text { Comparability } \\
\text { (Maximum } 2 \text { stars) }\end{array}$ & $\begin{array}{l}\text { The subjects in different outcome groups are comparable, } \\
\text { based on the study design or analysis. Confounding } \\
\text { factors are controlled. }\end{array}$ & 10 & 2 & - \\
\hline \multirow{2}{*}{$\begin{array}{l}\text { Outcome } \\
\text { (Maximum } 2 \text { stars) }\end{array}$} & Assessment of the outcome & 1 & 11 & - \\
\hline & Statistical test & 12 & - & - \\
\hline
\end{tabular}

1) RoB: risk of bias

Table 2. Summary of quality assessment for cohort studies

\begin{tabular}{|c|c|c|c|c|}
\hline \multicolumn{2}{|r|}{ Quality assessment criteria for cohort study } & $\begin{array}{l}\text { High quality } \\
\left(\text { Low RoB } B^{11}\right)\end{array}$ & $\begin{array}{l}\text { Low quality } \\
\text { (High RoB) }\end{array}$ & Unclear \\
\hline \multirow{4}{*}{$\begin{array}{l}\text { Selection } \\
\quad \text { (Maximum } 4 \text { stars) }\end{array}$} & Representativeness of the exposed cohort & 1 & 2 & - \\
\hline & Selection of the non exposed cohort & 3 & - & - \\
\hline & Ascertainment of exposure & 3 & - & - \\
\hline & $\begin{array}{l}\text { Demonstration that outcome of interest was not present at } \\
\text { start of study }\end{array}$ & 3 & - & - \\
\hline $\begin{array}{l}\text { Comparability } \\
\text { (Maximum } 2 \text { stars) }\end{array}$ & $\begin{array}{l}\text { Comparability of cohorts on the basis of the design or } \\
\text { analysis }\end{array}$ & 3 & - & - \\
\hline \multirow{3}{*}{$\begin{array}{l}\text { Outcome } \\
\text { (Maximum } 3 \text { stars) }\end{array}$} & Assessment of the outcome & 3 & - & - \\
\hline & Was follow-up long enough for outcomes to occur & 3 & - & - \\
\hline & Adequacy of follow up of cohorts & 2 & - & 1 \\
\hline
\end{tabular}

1) RoB: risk of bias

the dropouts (Table 1).

The three cohort studies had a lower risk of bias in most areas than the cross-sectional studies, in which two studies had a high risk of bias due to the researchers selecting the subjects of the study, and the risk of bias could not be judged for the other study because there was no description of the dropout in the process of tracking the subject (Table 2).

\section{Data integration}

This study extracted data from 15 primary studies after evaluating the risk of bias. In order to achieve a quantitative integration, we tried to analyze by research type (crosssectional study vs. cohort study), studies with the same result variables, or by country. However, quantitative integration was difficult because of the variety of countries, outcome variables, and methods of measuring the outcome variables even in the same type of research. For example, two out of five studies [7,15] performed in Korea used data from the Korea Youth Risk Behavior Web-based Survey (KYRBWS) and carried out a self-administered questionnaire on the breakfast eating habits of middle and high school students and the academic achievement was classified into five grades. However, quantitative data integration was impossible because the first study presented the number of times eating breakfast as a \% rather than frequency [7] and the second study presented the results by gender, not by academic achievement or the habit of eating breakfast [15]. The method of measuring the outcome variables was also diverse, as some studies asked the subjects to mark their grades on a scale (e.g. A-F, ExcellentGood, etc.) through self-administered questionnaires [4,9, $11,15,16]$ other studies measured public tests such as the College Scholastic Ability Test (CSAT) as a result variable [17-19] or measured the performance of certain subjects such as mathematics and English from school records [20-24]. In addition, four studies [7,15,23,25] had a common feature of dividing the academic achievement into five grades in the self-administered questionnaire, but did not present the overall results by dividing the outcome variables by gender. Therefore, we presented the results of technical integration by country since quantitative integration was not practical in reality. 
Table 3. Summary of studies investigating the effect of breakfast on academic performance in children and adolescents

\begin{tabular}{|c|c|c|c|c|c|c|c|}
\hline Authors & Country & Design & Sample & Definition of breakfast & AP measures & Results & RoB \\
\hline Kim et al. [15] & South Korea & $\begin{array}{l}\text { Cross } \\
\text { sectional } \\
\text { design }\end{array}$ & $\begin{array}{l}\mathrm{n}=359,264 \\
7^{\text {th }} \sim 12^{\text {th }} \text { grades } \\
\text { Female: } 174,463(48.6 \%) \\
\text { Male: } 184,801(51.4 \%) \\
\text { From: } \text { KYRBWS }^{1)}\end{array}$ & $\begin{array}{l}\text { Regularity of breakfast: } \\
\text { past } 7 \text { days } \\
6 \sim 7 \text { times/wk, } 3 \sim 5 \text { times/wk, } \\
1 \sim 2 \text { times/wk, } 0 \text { times/wk } \\
\text { Drinking a cup of juice or milk } \\
\text { was not counted as having } \\
\text { eaten breakfast }\end{array}$ & $\begin{array}{l}\text { Self-administered } \\
\text { questionnaire } \\
\text { Over last } 12 \text { months } \\
5 \text { level: } \\
\text { A (highest) } \sim \text { E (lowest) }\end{array}$ & $\begin{array}{l}\text { The regularity of consuming breakfast was } \\
\text { associated with higher school performance. } \\
\text { In group } A \text {, compared with never eating } \\
\text { breakfast, eating breakfast frequently } \\
\text { showed a high } \mathrm{AOR}^{2)} \text { with a dose-response } \\
\text { relationship. } \\
\text { Other school performance groups }(B \sim D) \\
\text { also showed dose-response relationships } \\
\text { eating breakfast. }\end{array}$ & $5^{*}$ \\
\hline $\begin{array}{l}\text { Stea and } \\
\text { Torstveit [20] }\end{array}$ & Norway & $\begin{array}{l}\text { Cross } \\
\text { sectional } \\
\text { design }\end{array}$ & $\begin{array}{l}\mathrm{n}=2,432 \\
\text { Aged } 1^{\text {st }} \text { grade at high } \\
\text { school } \\
\text { Female: } 1,258(51 \%) \\
\text { Malel: } 1,187(49 \%)\end{array}$ & $\begin{array}{l}\text { From never to } 7 \text { days/week, } \\
\text { regular breakfast means meals } \\
\text { every day }\end{array}$ & $\begin{array}{l}\text { Norwegian, English \& } \\
\text { Mathematics from } 0 \text { to } 6 \\
\text { (best) }\end{array}$ & $\begin{array}{l}\text { Increased odds of high academic } \\
\text { achievement in girls and boys who had a } \\
\text { regular consumption of breakfast (AOR: } 3.30 \\
(2.45-4.45) \text { and } \mathrm{AOR}^{2)}: 1.76(1.32-2.34) \text {, } \\
\text { respectively) }\end{array}$ & $2^{*}$ \\
\hline $\begin{array}{l}\text { Stroebele et al. } \\
\text { [16] }\end{array}$ & USA & $\begin{array}{l}\text { Cross } \\
\text { sectional } \\
\text { design }\end{array}$ & $\begin{array}{l}\mathrm{n}=1,095 \\
11 \text { elementary schools } \\
\text { enrolled in } 5^{\text {th }} \text { grade } \\
\text { From Climate, Safety and } \\
\text { Wellness Survey }\end{array}$ & & $\begin{array}{l}\text { Self-reported academic } \\
\text { performance, an 8-item } \\
\text { categorical ordinal scale } \\
\text { (dichotomized into } \\
\text { "Students with A's through } \\
\text { B's" and "Students with } \\
\text { some B's or lower grades") }\end{array}$ & $\begin{array}{l}\text { Significantly associated with academic } \\
\text { performance breakfast frequency }(<5 \\
\text { days/week) } \\
\text { The odds for children with good academic } \\
\text { performance to have daily breakfast per week } \\
\text { were higher than for children with poor } \\
\text { academic performance. }\end{array}$ & $4^{*}$ \\
\hline So [7] & South Korea & $\begin{array}{l}\text { Cross } \\
\text { sectional } \\
\text { design }\end{array}$ & $\begin{array}{l}\mathrm{n}=75,643 \\
7^{\text {th }} \sim 12^{\text {th }} \text { grades } \\
\text { Female: } 37,770 \\
\text { Male: } 37,873\end{array}$ & 1 (no breakfast) $\sim 8$ (every day) & $\begin{array}{l}\text { Self-reported academic } \\
\text { performance in the } \\
\text { previous } 12 \text { months. } \\
5 \text { possible responses: } \\
1 \text { (very high) } \sim 5 \text { (very low) } \\
\text { Divided into } 2 \text { groups for } \\
\text { multivariate logistic } \\
\text { regression: } \\
1 \text { (below-average) } \\
2 \text { (average-higher) }\end{array}$ & $\begin{array}{l}\text { Frequency of breakfast consumption was } \\
\text { positively related to academic performance } \\
\text { in both male and female healthy } \\
\text { adolescents. } \\
\text { Female adolescents are more likely to } \\
\text { experience the effects of breakfast } \\
\text { consumption on academic performance. }\end{array}$ & $4^{*}$ \\
\hline $\begin{array}{l}\text { Edwards et al. } \\
{[17]}\end{array}$ & USA & $\begin{array}{l}\text { Cross } \\
\text { sectional } \\
\text { design }\end{array}$ & $\begin{array}{l}\mathrm{n}=694 \\
6^{\text {th }} \text { graders } \\
\text { Female: } 359 \\
\text { Male: } 335\end{array}$ & & MAP $^{3)}$ tests & $\begin{array}{l}\text { Higher mean } \mathrm{MAP}^{3)} \text { math scores were } \\
\text { associated with those students who ate } \\
\text { breakfast more frequently. } \\
\text { But, } \mathrm{MAP}^{3)} \text { reading scores were not } \\
\text { associated with breakfast. }\end{array}$ & $5^{*}$ \\
\hline \multicolumn{8}{|c|}{$\begin{array}{l}\text { 1) KYRBWS: Korea Youth Risk Behavior Web-based Survey } \\
\text { 2) AOR, adjusted odds ratio; Cl, confidence interval } \\
\text { 3) MAP: measures of academic progress } \\
\text { 4) CSAT: College Scholastic Ability Test } \\
\text { 5) GPA: grade point average } \\
\text { 6) USBP: universal-free school breakfast program } \\
\text { 7) CTBS: comprehensive tests of basic skills }\end{array}$} \\
\hline
\end{tabular}


Table 3. Summary of studies investigating the effect of breakfast on academic performance in children and adolescents (continued)

\begin{tabular}{|c|c|c|c|c|c|c|c|}
\hline Authors & Country & Design & Sample & Definition of breakfast & AP measures & Results & RoB \\
\hline You et al. [11] & South Korea & $\begin{array}{l}\text { Cross } \\
\text { sectional } \\
\text { design }\end{array}$ & $\begin{array}{l}\mathrm{n}=237 \\
6^{\text {th }} \text { grade elementary } \\
\text { school } \\
\text { Female: } 118 \\
\text { Male: } 119\end{array}$ & & $\begin{array}{l}\text { Self-reported academic } \\
\text { performance } \\
3 \text { possible responses: high, } \\
\text { middle, low }\end{array}$ & $\begin{array}{l}\text { Academic performance is higher in the } \\
\text { female students who eating breakfast not } \\
\text { math. }\end{array}$ & $3^{*}$ \\
\hline Gajre et al. [21] & India & $\begin{array}{l}\text { Cross } \\
\text { sectional } \\
\text { design }\end{array}$ & $\begin{array}{l}\mathrm{n}=379 \\
6^{\text {th }} \sim 8^{\text {th }} \text { grades }\end{array}$ & $\begin{array}{l}\text { The first meal of the day that has } \\
\text { been taken in the morning, } \\
\text { before going to school. } \\
\text { Group I: regularly } \\
\text { Group II: irregular } \\
\text { Group III: never ate }\end{array}$ & $\begin{array}{l}\text { Previous year's annual } \\
\text { examination marks for } \\
\text { Math, Science and English }\end{array}$ & $\begin{array}{l}\text { Regular breakfast habit was significantly ( } p< \\
0.001 \text { ) associated with children's science } \\
\text { and English marks. }\end{array}$ & $5^{\star}$ \\
\hline Lien [22] & Norway & $\begin{array}{l}\text { Cross } \\
\text { sectional } \\
\text { design }\end{array}$ & $\begin{array}{l}\mathrm{n}=7,343 \\
10^{\text {th }} \text { grade } \\
\text { Male: } 3,611 \\
\text { Female: } 3,694\end{array}$ & $\begin{array}{l}\text { Seldom/never, } 1 \sim 2 / \text { week, } \\
3 \sim 4 \text { /week, } 5 \sim 6 / \text { week } \\
\text { Dichotomised seldom ( } \leq 2 / \text { week }) \\
\quad \& \text { often }(\geq 3 / \text { week })\end{array}$ & $\begin{array}{l}\text { Mathematics, written } \\
\text { Norwegian, English and } \\
\text { social science from } 1 \\
\text { (lowest) to } 6 \text { (highest) }\end{array}$ & $\begin{array}{l}\text { Eating breakfast regularly is associated with } \\
\text { improved academic performance in a } \\
\text { dose-response manner. }\end{array}$ & $4^{*}$ \\
\hline Choe et al. [9] & South Korea & $\begin{array}{l}\text { Cohort } \\
\text { study }\end{array}$ & $\begin{array}{l}\mathrm{n}=3,612 \\
\text { Freshmen in university } \\
\text { Male: } 1,030 \\
\text { Female: } 2,582\end{array}$ & $\begin{array}{l}\text { Frequency for having breakfast } \\
\text { Daily } \\
5 \sim 6 \text { days/week } \\
3 \sim 4 \text { days/week } \\
\text { Below } 2 \text { days/week }\end{array}$ & $\begin{array}{l}\text { Questionnaires through the } \\
\text { Internet } \\
\text { CSAT }^{4)}\end{array}$ & $\begin{array}{l}\text { The subjects who had their breakfast regularly } \\
\text { reported higher marks in the CSAT }{ }^{4)} \text { than } \\
\text { who rarely had breakfast ( } 294 \text { vs } 275 \text { ). }\end{array}$ & $2^{*}$ \\
\hline Kim et al. [10] & South Korea & $\begin{array}{l}\text { Cohort } \\
\text { study }\end{array}$ & $\begin{array}{l}\mathrm{n}=6,463 \\
\text { Grade: } 5,8, \& 11\end{array}$ & & $\begin{array}{l}\text { From the school record of } \\
\text { the last semester. } \\
\mathrm{GPA}^{5)} \text { : Korean, mathematics, } \\
\text { social studies, natural } \\
\text { science, physical } \\
\text { education, music, art, } \\
\text { ethics, and practical course } \\
\text { between } 1 \text { and } 5\end{array}$ & $\begin{array}{l}\text { Regularity of breakfast and lunch was } \\
\text { associated with academic performance in } \\
\text { most groups. Regularity was related to } \\
\text { higher } \mathrm{GPA}^{5} \text {, with the largest magnitude } \\
\text { being about one quarter of a point. }\end{array}$ & $7^{\star}$ \\
\hline $\begin{array}{l}\text { Abalkhail and } \\
\text { Shawky [23] }\end{array}$ & Saudi Arabia & $\begin{array}{l}\text { Cross } \\
\text { sectional } \\
\text { design }\end{array}$ & $\begin{array}{l}\mathrm{n}=800 \\
\text { Aged } 9 \sim 21 \text { years } \\
\text { Males: } 47.0 \% \\
\text { Females: } 53.0 \%\end{array}$ & & $\begin{array}{l}\text { School grades (total marks) } \\
\text { Fail: }<60 \% \text { of } \\
\text { Pass: }>60 \% \text { to }<70 \% \\
\text { Good: }>70 \text { to } 80 \% \\
\text { Very good: }>80 \% \text { to }<90 \% \\
\text { Excellent: }>90 \%\end{array}$ & $\begin{array}{l}\text { School achievement appeared to be } \\
\text { influenced by breakfast intake as the } \\
\text { students with poor school results. } \\
\text { Reported significantly less breakfast intake } \\
\text { than those with excellent results. }\end{array}$ & $4^{*}$ \\
\hline
\end{tabular}

1) KYRBWS: Korea Youth Risk Behavior Web-based Survey

2) $A O R$, adjusted odds ratio; $\mathrm{Cl}$, confidence interval

3) MAP: measures of academic progress

4) CSAT: College Scholastic Ability Test

5) GPA: grade point average

6) USBP: universal-free school breakfast program

7) CTBS: comprehensive tests of basic skills 
Table 3. Summary of studies investigating the effect of breakfast on academic performance in children and adolescents (continued)

\begin{tabular}{|c|c|c|c|c|c|c|c|}
\hline Authors & Country & Design & Sample & Definition of breakfast & AP measures & Results & RoB \\
\hline $\begin{array}{l}\text { Kleinman et al. } \\
\text { [25] }\end{array}$ & USA & $\begin{array}{l}\text { Cohort } \\
\text { study }\end{array}$ & $\begin{array}{l}\mathrm{n}=97 \\
3^{\text {rd }} \sim 6^{\text {th }} \text { grades } \\
\text { Male: } 40(41 \%) \\
\text { Female: } 47(59 \%)\end{array}$ & $\begin{array}{l}\text { USBP }^{6)} \\
\text { Often: ate breakfast } 80 \% \\
\text { More sometimes: } 20 \sim 79 \% \\
\text { Rarely: }<20 \%\end{array}$ & $\begin{array}{l}\text { Official school records Math, } \\
\text { Reading, Science, and } \\
\text { Social Studies for the full } \\
\text { pre-USBP } \\
4.0 \text { grading system }\end{array}$ & $\begin{array}{l}\text { Participation in a school breakfast program } \\
\text { enhanced was associated with significant } \\
\text { improvements in student academic } \\
\text { performance especially in math. }\end{array}$ & $8^{*}$ \\
\hline $\begin{array}{l}\text { Murphy et al. } \\
\text { [24] }\end{array}$ & USA & $\begin{array}{l}\text { Cross } \\
\text { sectional } \\
\text { design }\end{array}$ & $\begin{array}{l}\mathrm{n}=133 \\
\text { Grade: } 3 \sim 8 \\
\text { Male: } 58(44 \%) \\
\text { Female: } 75(56 \%)\end{array}$ & $\begin{array}{l}\text { USBP }{ }^{6)} \\
\text { Regular school breakfast for free } \\
\text { to all students }\end{array}$ & $\begin{array}{l}\text { Math, science, social studies } \\
\text { and reading } 4.0 \text { grading } \\
\text { system }\end{array}$ & $\begin{array}{l}\text { Children who increased rate of breakfast were } \\
\text { significantly more likely to increase math } \\
\text { grades }(+0.3) \text { than children who had the } \\
\text { same or decreased breakfast }(-0.1 \text { and }-0.9) \text {. }\end{array}$ & $3^{*}$ \\
\hline Simeon [18] & Jamaica & $\begin{array}{l}\text { Cohort } \\
\text { study }\end{array}$ & $\begin{array}{l}n=115 \\
\text { Grade: } 7\end{array}$ & $\begin{array}{l}\text { School meal ( } 100 \mathrm{~mL} \text { milk and } \\
\text { either a slice of cake or a } \\
\text { meat-filled pastry) }\end{array}$ & $\begin{array}{l}\text { Wide Range } \\
\text { Achievement Test, which } \\
\text { included arithmetic, spelling, } \\
\text { and reading subtests. }\end{array}$ & $\begin{array}{l}\text { Received the school meal group performed } \\
\text { better on the arithmetic test than the syrup } \\
\text { or nothing served group }(p<0.01) \text {. }\end{array}$ & $8^{*}$ \\
\hline $\begin{array}{l}\text { Meyers et al. } \\
\text { [19] }\end{array}$ & USA & $\begin{array}{l}\text { Cohort } \\
\text { study }\end{array}$ & $\begin{array}{l}\mathrm{n}=1,021 \\
\text { Grade: } 3 \sim 6 \\
\text { Male: } 518(50.7 \%) \\
\text { Female: } 503(49.3 \%)\end{array}$ & & $\begin{array}{l}\mathrm{CTBS}^{7)} \text { scores: language, } \\
\text { reading, math }\end{array}$ & $\begin{array}{l}\text { Participation in the program by low-income } \\
\text { children had a significant association with } \\
\text { improvement in standardized achievement } \\
\text { test scores and rates of absence and } \\
\text { tardiness. }\end{array}$ & $7^{\star}$ \\
\hline
\end{tabular}

1) KYRBWS: Korea Youth Risk Behavior Web-based Survey

2) $A O R$, adjusted odds ratio; $\mathrm{Cl}$, confidence interval

3) MAP: measures of academic progress

4) CSAT: College Scholastic Ability Test

5) GPA: grade point average

6) USBP: universal-free school breakfast program

7) CTBS: comprehensive tests of basic skills 


\section{Results}

The primary literature included in this study was a total of 15 papers, 12 of which were cross-sectional studies and three were cohort studies, five each from Korea [7,9-11,15] and the US [16,17,19,24,25] two from Norway [20,22] and one each from India [21] Saudi Arabia [23] and Jamaica [18] (Table 3). In terms for the subjects of the studies, five studies were performed on elementary school students only $[11,16,17,19,24]$ and one study each on middle school students [18] and college freshmen [9] respectively. In addition, there were two studies each on elementary, middle, and high school students [10,23] elementary and middle school students [21,25] and middle and high school students $[7,15]$. The number of subjects ranged from a maximum of about 360,000 [15] to a minimum of 97 [24]. The academic achievements were measured by questionnaires, in which five studies allowed the subjects to mark their own level of academic achievement [10,20-23] five studies derived the results of certain subjects such as math and English from official school report cards [10,20-23] and three studies applied the results of official tests such as the CSAT [17-19].

Two out of five studies [7,15] performed in Korea used data from the KYRBWS and carried out a self-administered questionnaire on the breakfast eating habits of middle and high school students and the academic achievement classified into five grades. All five studies conducted in Korea showed that students who regularly had breakfast showed higher academic achievement than the students who did not, and even if there was no statistical significance, showed a positive correlation as more numbers of breakfasts led to higher levels of academic achievement. In other words, students who regularly ate breakfast had a significantly higher academic performance than students who did not eat breakfast at all about $1.9 \sim 2.34$ times $[7,15]$. In addition, the CSAT scores of students who regularly had breakfast $(291.7 \pm 65.9)$ were analyzed to be about 20 points higher than students who had breakfast only when they wanted to $(277.5 \pm 65.2)$ or when they were hungry $(270.4 \pm 68.1)$, indicating that breakfast had a major influence on the student's academic performance.

A total of five studies were conducted in the US (three cross-sectional studies and two cohort studies), mostly for elementary students $[16,17,19,24]$ and in which three studies analyzed the correlation between the effect of the
Universal School Breakfast Program (USBP) and academic achievement [19,24,25]. Unlike Korea, the studies performed in the US analyzed the relationship between the academic achievement by subject and breakfast, in which the results showed that math was especially related to breakfast. In other words, Kleinman et al. [25], Murphy et al. [24] and Meyers [19] studies analyzed the changes in academic achievement before and after USBP by setting the grades of math, reading, science, and social studies as the outcome variables. The results of the studies showed that the grades of subjects such as reading, except for math, showed no statistical relation with breakfast, while only math showed improved results according to a regular breakfast or as the number of having breakfast increased.

Two cross-sectional studies were performed in Norway for first-year high school students, and the results of analyzing the relationship between the grades in Norwegian, English, and mathematics and eating breakfast showed that students who regularly had breakfast have higher academic achievements regardless of the gender. In other words, according to the study [22] the average grade of all subjects of the students who regularly had breakfast was more than twice as high as that of students who did not eat breakfast at all, and the results of the Stea and Torstveit [20] also showed that students who had breakfast every day are about 3.3 times more likely to be in the academic achievement group with a score of at least four out of six [20].

The three studies performed in India and other countries also showed a close relationship between breakfast and academic achievement. Gajre et al. [21] reported that breakfast was statistically significantly related to science and English grades but not to math, while Simeon [18] showed that the students with regular breakfast had significantly higher math scores than those who did not. In addition, Abalkhail and Shawky [23] found that students with excellent grades had a higher rate of regular breakfast compared to the students who did not $(87.8 \%$ vs $73.0 \%)$.

This study was performed on primary studies that examined whether eating breakfast influenced academic achievement. We searched a total of 274 studies through six databases and included a total of 15 primary studies in which 12 studies were cross-sectional and three were cohort studies. The primary studies included in this study were published from 1989 to 2016, in which all five studies [7,9-11,15] from Korea were performed after 2003, 
indicating the high interest in the relationship between breakfast and academic achievement in recent years.

The primary studies included in this study chose elementary, middle, high school, and college students as the subjects, in which five studies were performed on elementary school students, and most studies defined breakfast as school breakfast programs or any type of oral intake before school. In terms of academic achievement, the studies made students fill in the overall grade of all subjects in sections, or selected specific subjects and selected the grades of each subject or the overall average of the selected subjects as the outcome variables. The outcome variables were diverse and only a few cases provided raw data such as the frequency of having breakfast with respect to academic achievement among the primary studies, so it is difficult to attempt a meta-analysis, such as providing an adjusted odds ratio or percentage (\%).

Since a quantitative integration of the primary studies was difficult to achieve such as performing a meta-analysis, this study performed a descriptive analysis of all the 15 studies and the results have shown that eating breakfast has a significant effect on academic achievement. In other words, students who regularly had breakfast showed more than twice the academic performance compared to those who did not have breakfast, and even though the math scores of students who had breakfast were statistically significantly higher, none of the study results inferred the reason. Previous systematic literature reviews $[12,13]$ also failed to attempt quantitative integrations such as metaanalysis, but showed similar results to this study by presenting results that the habit of eating breakfast during adolescence has a significant influence on cognitive ability and academic achievement. In particular, it was analyzed that adolescents from low-income households that had regular breakfast showed higher academic performance than those who did not have breakfast, so different approaches were emphasized according to the socioeconomic level of the parents.

Research on whether or not breakfast affects academic achievement is a topic of great interest among researchers as well as the general public, but since the results of the previous studies were not consistent, this study questioned whether breakfast should be encouraged. Although quantitative integration was impossible, the research results of all 15 studies included in this study showed the importance of eating breakfast during adolescence by presenting that academic achievement increases with regular or more frequent habits of eating breakfast. However, as a result of this systematic literature review, the study suggests the following to present a more clear statistical basis by enabling quantitative integration between breakfast and academic achievement. First, in order to obtain more accurate and reliable data on the relationship between breakfast and academic achievement as a scientific basis, studies designed with a high level of evidence should be performed in future. There were no randomized studies among the 15 primary studies included in this study and most of which were cross-sectional studies, so there was a low level of evidence to explain the causal relationship between breakfast and academic achievement. Second, in terms of measuring the academic achievement, many studies questioned the reliability of the outcome variables by requiring the participants to fill out their academic achievements on the questionnaires themselves, rather than extracting scores or grades from official records such as the report cards, therefore, future studies will need to have in-depth discussions about the source of data on academic achievement.

\section{ORCID}

Eun Young Jeong: https://orcid.org/0000-0002-1107-3817

\section{References}

1. Ministry of Health and Welfare; Korea Centers for Disease Control and Prevention. Korea health statistics 2014: Korea national health and nutrition examination survey (KNHANES VI-2). Cheongju: Korea Centers for Disease Control and Prevention; 2015.

2. Dickie NH, Bender AE. Breakfast and performance in school children. Br J Nutr 1982; 48(3): 483-496.

3. Cromer BA, Tarnowski KJ, Stein AM, Harton P, Thornton DJ. The school breakfast program and cognition in adolescents. $J$ Dev Behav Pediatr 1990; 11(6): 295-300.

4. López I, de Andraca I, Perales CG, Heresi E, Castillo M, Colombo M. Breakfast omission and cognitive performance of normal, wasted and stunted schoolchildren. Eur J Clin Nutr 1993; 47(8): 533-542.

5. Wyon DP, Abrahamsson L, Järtelius M, Fletcher RJ. An experimental study of the effects of energy intake at breakfast on the test performance of 10-year-old children in school. Int J Food Sci Nutr 1997; 48(1): 5-12.

6. Wesnes KA, Pincock C, Richardson D, Helm G, Hails S. Breakfast reduces declines in attention and memory over the morning in schoolchildren. Appetite 2003; 41(3): 329-331. 
128 / The influence of breakfast on the academic performance: systematic review

7. So WY. Association between frequency of breakfast consumption and academic performance in healthy Korean adolescents. Iran J Public Health 2013; 42(1): 25-32.

8. Yang SJ, Kim K, Hwang JY. Effect of 'Breakfast Club Program' on dietary behaviors and school life in high school students residing in Seoul metropolitan areas. J Korean Soc Food Sci Nutr 2015; 44(7): 1000-1006.

9. Choe JS, Chun HK, Chung GJ, Nam HJ. Relations between the dietary habit and academic achievement, subjective health judgement, physical status of high school students. J Korean Soc Food Sci Nutr 2003; 32(4): 627-635.

10. Kim HY, Frongillo EA, Han SS, Oh SY, Kim WK, Jang YA, et al. Academic performance of Korean children is associated with dietary behaviours and physical status. Asia Pac J Clin Nutr 2003; 12(2): 186-192.

11. You JS, Kim SM, Chang KJ. Nutritional knowledge and dietary behavior of the 6th grade elementary school students in Daejeon area by gender and skipping breakfast. Korean J Nutr 2009; 42(3): 256-267.

12. Adolphus K, Lawton CL, Dye L. The effects of breakfast on behavior and academic performance in children and adolescents. Front Hum Neurosci 2013; 7: 425.

13. Adolphus K, Lawton CL, Champ CL, Dye L. The effects of breakfast and breakfast composition on cognition in children and adolescents: a systematic review. Adv Nutr 2016; 7(3): 590S-612S.

14. Wells GA, Shea B, O'Connell D, Peterson J, Welch V, Losos $\mathrm{M}$, et al. The Newcastle-Ottawa Scale (NOS) for assessing the quality of nonrandomised studies in meta-analyses [Internet]. Ottawa: Ottawa Hospital Research Institute; 2013 [cited 2013 Mar 15]. Available from: http://www.ohri.ca/programs/clinical_ epidemiology/nosgen.pdf.

15. Kim SY, Sim S, Park B, Kong IG, Kim JH, Choi HG. Dietary habits are associated with school performance in adolescents. Medicine (Baltimore) 2016; 95(12): e3096.
16. Stroebele N, McNally J, Plog A, Siegfried S, Hill JO. The association of self-reported sleep, weight status, and academic performance in fifth-grade students. J Sch Health 2013; 83(2): 77-84.

17. Edwards JU, Mauch L, Winkelman MR. Relationship of nutrition and physical activity behaviors and fitness measures to academic performance for sixth graders in a midwest city school district. J Sch Health 2011; 81(2): 65-73.

18. Simeon DT. School feeding in Jamaica: a review of its evaluation. Am J Clin Nutr 1998; 67(4): 790S-794S.

19. Meyers AF, Sampson AE, Weitzman M, Rogers BL, Kayne H. School Breakfast Program and school performance. Am J Dis Child 1989; 143(10): 1234-1239.

20. Stea TH, Torstveit MK. Association of lifestyle habits and academic achievement in Norwegian adolescents: a crosssectional study. BMC Public Health 2014; 14: 829.

21. Gajre NS, Fernandez S, Balakrishna N, Vazir S. Breakfast eating habit and its influence on attention-concentration, immediate memory and school achievement. Indian Pediatr 2008; 45(10): 824-828.

22. Lien L. Is breakfast consumption related to mental distress and academic performance in adolescents? Public Health Nutr 2007; 10(4): $422-428$.

23. Abalkhail B, Shawky S. Prevalence of daily breakfast intake, iron deficiency anaemia and awareness of being anaemic among Saudi school students. Int J Food Sci Nutr 2002; 53(6): 519-528.

24. Murphy JM, Pagano ME, Nachmani J, Sperling P, Kane S, Kleinman RE. The relationship of school breakfast to psychosocial and academic functioning: cross-sectional and longitudinal observations in an inner-city school sample. Arch Pediatr Adolesc Med 1998; 152(9): 899-907.

25. Kleinman RE, Hall S, Green H, Korzec-Ramirez D, Patton K, Pagano ME, et al. Diet, breakfast, and academic performance in children. Ann Nutr Metab 2002; 46 Suppl 1: 24-30. 